\title{
Two distinct regions of HA2 glycopolypeptide of influenza virus hemagglutinin elicit cross-protective immunity against influenza
}

\author{
J. JANULÍKOVÁ, Z. STANEKOVÁ, V. MUCHA, F. KOSTOLANSKÝ, E. VAREČKOVÁ*
}

Institute of Virology, Slovak Academy of Sciences, Dúbravská cesta 9, 84505 Bratislava, Slovak Republic

Received May 25, 2012; accepted May 30, 2012

\begin{abstract}
Summary. - Currently, a new trend in development of vaccines against influenza with broader spectrum of efficacy is focused on conserved antigens of influenza virus. The HA2 glycopolypeptide (HA2 gp) is one of conserved antigens, potentially suitable as immunogens inducing cross-protection against influenza. We selected two distinct domains of HA2 gp originating from influenza A virus (IAV) of H3 subtype for induction of antiviral immune response: the ectodomain (EHA2) comprising aa 23-185 and the fusion peptide (FP) comprising $\mathrm{N}$-terminal aa 1-38. BALB/c mice were immunized with three doses of EHA2 and FP, respectively, and subsequently challenged with $2 \mathrm{LD}_{50}$ of IAV of homologous (H3) or heterologous (H7) HA subtype. Both peptides induced significant antibody response and protected mice against the lethal infection. The most efficient protection was achieved with EHA2 against homologous virus.
\end{abstract}

Keywords: influenza A virus; cross-protection; HA2 glycopolypeptide; HA2 ectodomain; fusion peptide; mice; vaccine

\section{Introduction}

IAVs cause acute respiratory diseases in humans, which can often be accompanied by health complications with a severe course and even a fatal end. The control of spread of infection can be achieved by vaccination or therapy with antiviral substances, however, both have limited efficacy. The yearly repetition of influenza epidemics is the consequence of high and unpredictable variability of IAVs. The low fidelity of viral RNA-polymerase, the RNA segmented genome as well as the wide host specificity of IAVs, are the main factors contributing to their mutational rate. Currently used vaccines induce virus-neutralizing antibodies, targeted to HA1 gp localized

*Corresponding author. E-mail: viruevar@savba.sk; phone: +421259302427.

Abbreviations: A/Chicken/Germany/34 (H7N1) virus, Rostock strain; $\mathrm{A} / \mathrm{Miss}=\mathrm{A} / \mathrm{Mississippi} / 1 / 85(\mathrm{H} 3 \mathrm{~N} 2)$ virus; $\mathrm{A} /$ Rostock = avian HA = hemagglutinin; EHA2 = ectodomain of HA2 gp; $\mathrm{FA}=$ Freund $\mathbf{s}$ adjuvant; $\mathrm{FP}=$ fusion peptide; $\mathrm{HA} 0=\mathrm{HA}$ precursor; HA1 = HA1 glycopolypeptide; HA2 = HA2 glycopolypeptide; $\operatorname{IAV}(\mathrm{s})=$ influenza $\mathrm{A}$ virus(es); MAb = monoclonal antibody; vRNA = viral RNA; p.i. $=$ post infection on the globular part of HA, which is variable. Owing to the rapid antigenic drift of IAVs, these vaccines become ineffective against newly emerging IAVs, which infect people lacking specific immunity. Therefore, based on influenza surveillance worldwide, vaccination strains must be annually updated. Moreover, preparation of actual vaccines takes time, which can be critical in case a new pandemic virus is emerging. A highly pathogenic IAV (H5N1) that has recently infected humans in several continents, represents a pandemic threat. It can become transmissible from person to person and cause a severe infection by cumulative drift changes or by reassortment. Therefore, new approaches to prevention providing a broad cross-protective immunity to influenza are focused on the conserved antigens of IAVs. A passive immunization with cross-protective antibodies has been successfully applied to several experimental models (Gocník et al., 2007; Throsby et al., 2008; Prabhu et al., 2009; Yoshida et al., 2009; Wang et al, 2010; Corti et al., 2011; Király et al., 2011). However, the passive immunization is limited to therapeutic purposes only and for effective prevention a new strategy of active immunization is required.

Many studies have been focused on the M2 protein (Okuda et al., 2001; Fan et al., 2004; Liu et al., 2004; DeFilette et al., 2006; Hoelscher et al., 2006; DeFilette et al., 2008a,b; Huleatt 
et al., 2008; Zhang et al., 2009; Li et al., 2011; Park et al., 2011; Staneková et al., 2011), but recently also the conserved part of HA, HA2 gp, was used as an inductor of cross-protective immunity (Okuno et al., 1993; Horváth et al., 1998; Gocník et al., 2008; Sui et al., 2009; Bommakanti et al., 2010; Steel et al., 2010; Wang et al., 2010; Staneková et al., 2011). The latter was the subject of our interest for several years. HA2 gp plays an important role in the virus entry into the cell. IAV HA is synthesized as a precursor (HA0), which is subsequently glycosylated, trimerized and proteolytically cleaved into two parts, HA1 and HA2. After cleavage they remain connected by disulphide bond. The attachment of virus to cell surface is mediated by receptor-binding site on HA1 gp and virus is then endocyted. In endosomes, acidic $\mathrm{pH}$ induces major conformational changes in the HA molecule, leading to exposure of FP at the N-terminus of HA2 and subsequent fusion of viral and endosomal membranes. The virus genome is released into the cytoplasm and transported to the site of virus replication, the cell nucleus.

HA2 representing the major part of the HA stem is highly conserved across IAVs within a subtype (Nobusawa et al., 1991; Gerhard et al., 2006). Moreover, there are some regions of HA2 gp, which are conserved also among various subtypes (Varečková et al., 2002, 2008). As we have shown previously, HA2 gp is immunogenic and able to induce a protective antibody response in mice (Varečková et al., 2003a; Gocník et al., 2008). The most conserved part of HA2 gp is its N-terminus, FP. Its sequence analysis revealed that aa 3-11 exhibit even an 100\% identity among all influenza subtypes (Nobusawa et al., 1991). Though HA2-specific antibodies are induced also during a natural IAV infection of humans (Styk et al., 1979), their level is low and not effective enough to protect against the infection, as epitopes of HA2 gp are weak natural immunogens (Staneková et al., 2012). These findings led us to assume that an effective antiviral protection could be achieved by targeted immunization with HA2 gp.

Therefore, in this work, we examined the in vivo crossprotective potential of immunization by two peptides originating from HA2 gp of $\mathrm{H} 3$ subtype, EHA2 comprising aa $23-185$ and N-terminal aa 1-38, FP. BALB/c mice, lethally infected with IAVs of $\mathrm{H} 3$ or $\mathrm{H} 7$ subtype served as an experimental model, in which main parameters of infection were monitored.

\section{Materials and Methods}

Viruses. Influenza virus A/Mississippi/1/85 (H3N2) (abbreviated as A/Miss) and avian A/Chicken/Germany/34 (H7N1) virus, Rostock strain (abbreviated as A/Rostock) originated from the collection of viruses of Institute of Virology, Slovak Academy of Sciences. Viruses were propagated in fertilized chicken eggs and purified by differential sucrose density gradient centrifugation (Russ et al., 1974).

EHA2 was expressed in Escherichia coli BL21 transformed with pLM-1 plasmid encoding the region of aa 23-185 of HA2 gp of recombinant X-31 virus. The latter originated from A/Aichi/2/68 (H3N2) virus, kindly provided by Drs D.C. Wiley and J. Chen, Harvard University, Boston, USA. The expressed EHA2 was purified as described, the final step consisting of affinity chromatography on $\mathrm{CNBr}$ Sepharose (Sigma) coupled with HA2-specific monoclonal antibody (MAb) IIF4 (Chen et al., 1995, 1999; Varečková et al., 1993).

FP containing $38 \mathrm{~N}$-terminal amino acids of HA2 gp of H3 subtype (1-GIFGAIAGFIENGWEGMVDGWYGFRHQNSEG TGQAADL-38) with $\mathrm{M}_{\mathrm{r}}$ of 4059.44 (94.8\% purity) was supplied by ProImmune (Oxford, UK). Its sequence was based on that of IAV (H3N2) 1985 strain (Acc. No. ABD61777). Low immunogenicity of FP as a small hydrophobic molecule was enhanced by conjugation with KLH. Briefly, $2 \mathrm{mg} / \mathrm{ml} \mathrm{FP}$ was mixed with $2 \mathrm{mg} / \mathrm{ml} \mathrm{KLH}$, both in PBS. Glutaraldehyde was added to final concentration of $2.5 \%$ and the mixture was incubated for 50 mins at RT. The reaction was stopped with glycine added to final concentration of $0.03 \mathrm{~mol} / \mathrm{l}$ and the mixture was dialyzed against $\mathrm{PBS}$ at $4^{\circ} \mathrm{C}$ overnight. Aliquots of the conjugated peptide were stored at $-20^{\circ} \mathrm{C}$.

Adaptation of viruses to mice. Six-week-old BALB/c mice were infected intranasally under light anesthesia with $40 \mu \mathrm{l}$ of allantoic fluid containing infectious A/Miss or A/Rostock. After 2 days the mice were sacrificed, the lungs were homogenized with $1 \mathrm{ml}$ of PBS, cell debris were pelleted and $40 \mu \mathrm{l}$ of the obtained supernatant was used for further infection of mice. After 6 subsequent mouse passages the virus was propagated in 9-day-old chicken embryos. Virus titer was determined by standard micro-haemagglutination test using guinea pig erythrocytes.

Immunization and challenge. Six-week-old BALB/c mice were immunized intraperitoneally with three doses of EHA2 and FP, respectively, supplemented with inulin and FA as adjuvants, in two-week intervals. Since FP is a small hydrophobic molecule of low immunogenicity, the latter was enhanced by conjugation of FP to KLH. Single immunization dose contained EHA2 (10 $\mu \mathrm{g} / \mathrm{mouse})$ or FP conjugate $(30 \mu \mathrm{g} / \mathrm{mouse})$, inulin $(100 \mu \mathrm{g} / \mathrm{mouse})$ (Cooper and Steele, 1988; Petrovsky, 2006) and FA (v/v FA: antigen 1:2) in a total volume of $400 \mu \mathrm{l}$. Control mice were given PBS. Two weeks after the third dose, mice were challenged intranasally under light anaesthesia with $2 \mathrm{LD}_{50}(40 \mu \mathrm{l})$ of $\mathrm{A} /$ Miss or A/Rostock. The course of the infection including survival, body weight change, the presence of infectious virus and viral RNA (vRNA) in the lungs, was monitored for 14 days post infection (p.i.).

Rapid culture assay (RCA). To determine infectious virus in the lungs two mice per group in two-day intervals were sacrificed, the lungs were homogenized with $1 \mathrm{ml}$ of PBS, cell debris were pelleted and the supernatant was assayed for infectious virus as described (Tkáčová et al., 1997). Briefly, MDCK cells were cultured in DMEM with 5\% FBS in 96-well plates for $24 \mathrm{hrs}$ to a density of $5 \times 10^{4}$ cells/well. Two-fold dilutions of the supernatant in PBS were added to wells with cells for $45 \mathrm{~min}$ at $37^{\circ} \mathrm{C}$. There- 
after the inoculum was removed and a serum-free Ultra-MDCK medium was added. After $18 \mathrm{hr}$-incubation at $37^{\circ} \mathrm{C}$ and $5 \% \mathrm{CO}_{2}$ cells were fixed with methanol and the virus was detected using MAb 107L specific to IAV nucleoprotein (Varečková et al., 1995) $(1.5 \mu \mathrm{g} / \mathrm{ml}$ in PBS with $5 \%$ dry milk). After the incubation with HRP-conjugated goat anti-mouse IgG (90 min r.t.) positive reaction was visualized by addition of substrate solution containing 3-amino 9-ethyl-carbazole with 0,03\% $\mathrm{H}_{2} \mathrm{O}_{2}$. Differentiated red colored cells, identified by light microscopy, were considered as positive.

RT-PCR. To detect vRNA in the lungs $200 \mu \mathrm{l}$ of lung cell homogenate was mixed with $500 \mu$ lof Instapure ${ }^{\text {TM }}$ System (Eurogentec). Total RNA was extracted by phenol-chloroform and examined for vRNA by RT-PCR. The RT step with random heptamer primers (Invitrogen) was followed by PCR amplification of specific virus nucleoprotein gene segment as described (Varečková et al., 2006).

ELISA. To detect specific antibodies in mouse sera blood samples were collected from sinus orbitalis in two-week intervals before immunization and after each immunization dose. The obtained sera were tested for the presence of specific antibodies by sandwich ELISA. Briefly, EHA2 (80 ng/100 $\mu$ / well) or FP (500 ng/100 $\mu \mathrm{l} /$ well) was adsorbed onto 96 -well plates for 24 hrs, the wells were blocked with $0.5 \%$ ovalbumine for $1 \mathrm{hr}$ at RT, washed and incubated with 2 -fold dilutions of sera (100 $\mu$ l/well) in PBS with $0.5 \%$ ovalbumine for $90 \mathrm{~min}$. Specific antibodies were detected by a HRP-conjugated goat anti-mouse IgG after 90 min incubation and addition of the substrate solution containing ortho-phenylendiamine with $0,03 \% \mathrm{H}_{2} \mathrm{O}_{2}$. The reaction was stopped with $1 \mathrm{M} \mathrm{HCl}$ and $\mathrm{A}_{495}$ was read.

\section{Results}

We examined the effect of immunization with conserved parts of IAV HA2 gp of H3 subtype, EHA2 comprising aa 23-185 and FP consisting of N-terminal aa 1-38 on the course of lethal influenza infection of mice with homologous IAV of $\mathrm{H} 3$ subtype of human origin (A/Mississippi/1/85(H3N2)) and heterologous, highly pathogenic avian IAV of $\mathrm{H} 7$ subtype (A/Chicken/Germany/34 (H7N1), Rostock strain).

\section{Antibody response of mice to two fragments of $\mathrm{HA} 2 \mathrm{gp}$}

First we analyzed the antibody response elicited by immunization of mice with three doses of EHA2 and FP, respectively, by ELISA.

A noticeable production of HA2-specific antibodies, in particular an antibody titer of 5,140 was obtained already after the first dose of EHA2. The second dose raised the antibody titer to $1,030 \times 10^{3}$. No further increase of HA2-specific antibodies was registered after the third immunization step (Fig. 1a). (a)

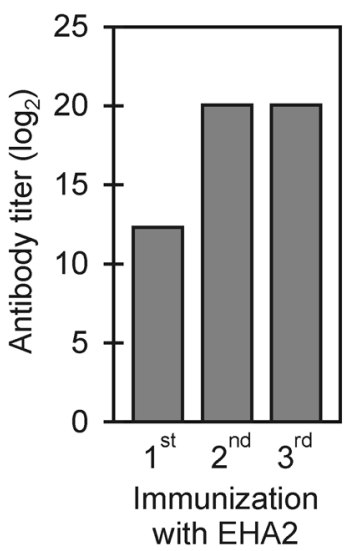

(b)

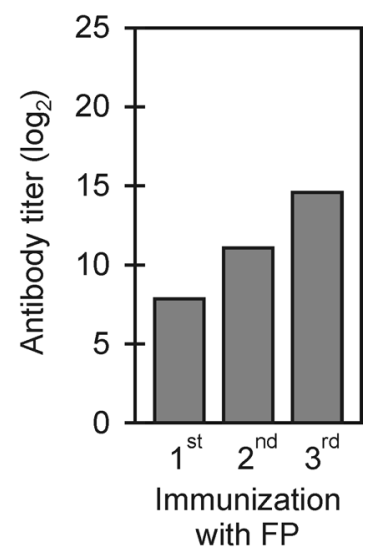

Fig. 1

Antibody response of mice to immunization with EHA2 (a) and FP (b)

The immunization with another part of HA2 gp, FP, resulted in a stepwise increase of the antibody titer up to 26,800 after the third dose (Fig. 1b).

\section{Cross-protective effect of immunization with EHA2 on} lethal influenza infection of mice

The course of infection in mice immunized with EHA2 and challenged with homologous influenza virus

Immunization of mice $(n=13)$ with three doses of EHA2 significantly increased the survival of mice after challenge with $2 \mathrm{LD}_{50}$ of homologous A/Miss (H3N2) virus from $27 \%$ in non-immunized controls $(n=15)$ up to $100 \%$ ( $p=0.0001$ ) (Fig. 2 ). Control mice exhibited clinical symptoms of influenza such as scrubby fur, loss

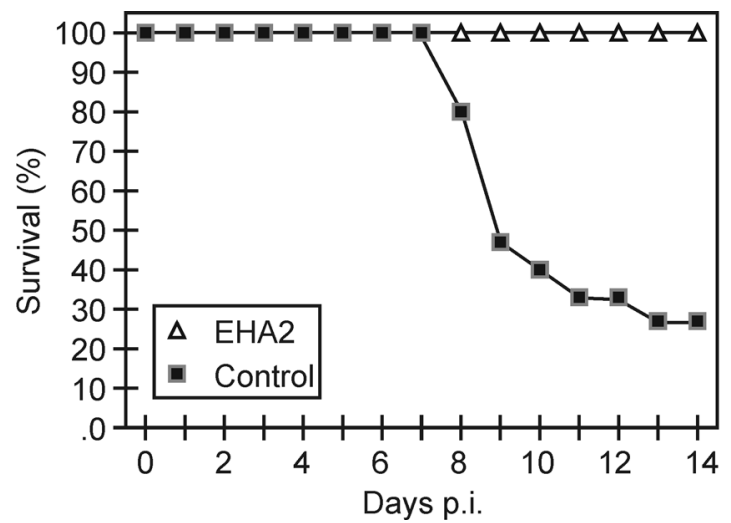

Fig. 2

Survival of mice immunized with EHA2 and challenged with homologous influenza virus 


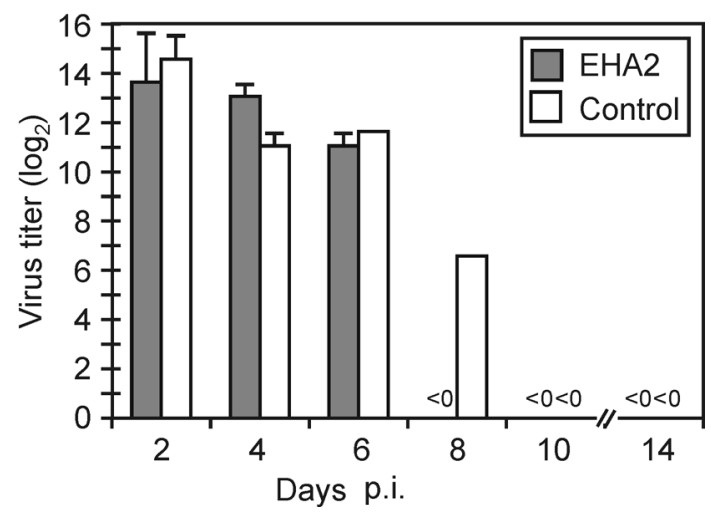

Fig. 3

Infectious virus in lungs of mice immunized with EHA2 and challenged with homologous influenza virus

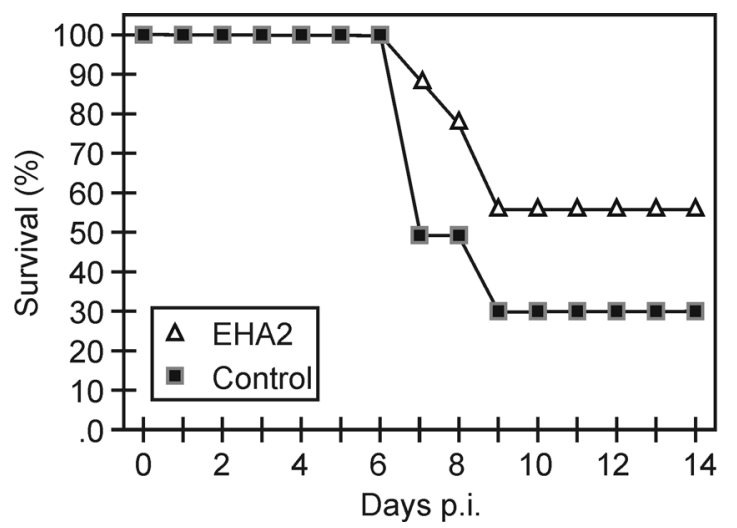

Fig. 4

Survival of mice immunized with EHA2 and challenged with heterologous influenza virus

munized mice was observed by 4 days earlier compared to control mice (Table 2).

We can therefore conclude that the immunization with EHA2 gp conferred to mice a significant and complete protection against IAV of homologous subtype and a partial protection against a heterologous, highly pathogenic avian IAV. in immunized mice compared to control mice. Infectious virus was eliminated from lungs of immunized mice by two days earlier (day 8 p.i.) compared to control mice (day 10 p.i.) (Fig. 3). Similarly, vRNA was also eliminated from lungs of immunized mice earlier (day 8 p.i.) compared to control mice (day 14 p.i.) (Table 1).

Table 1. Detection of vRNA in lungs of mice immunized with EHA2 and challenged with homologous virus

\begin{tabular}{lcccccc}
\hline \multirow{2}{*}{ Immunogen } & \multicolumn{7}{c}{ Days p.i. } \\
\cline { 2 - 7 } & 2 & 4 & 6 & 8 & 10 & 14 \\
\hline EHA2 & $+/+$ & $+/+$ & $+/+$ & $-/-$ & - & - \\
Control & $+/+$ & $+/+$ & $\mathrm{ND} /+$ & $-/+$ & + & - \\
\hline
\end{tabular}

The course of infection in mice immunized with EHA2 and challenged with heterologous influenza virus

To assess the cross-protective potential of EHA2 immunization, a heterologous, highly pathogenic avian A/Rostock (H7N1) virus was used for challenge. The immunization of mice $(n=9)$ with three doses of EHA2 slightly increased their survival from $30 \%$ in control mice $(n=10)$ to $56 \%(\mathrm{p}=0.3698)$ (Fig. 4). During the first days after the challenge, the course of infection was relatively mild until day 7 p.i. Thereafter, clinical symptoms worsened and mice started to die. The elimination of vRNA from lungs of im-
Table 2. Detection of vRNA in lungs of mice immunized with EHA2 and challenged with heterologous virus

\begin{tabular}{lcccccc}
\hline \multirow{2}{*}{ Immunogen } & \multicolumn{7}{c}{ Days p.i. } \\
\cline { 2 - 7 } & 2 & 4 & 6 & 8 & 10 & 14 \\
\hline EHA2 & - & $+/-$ & $+/-$ & $+/+$ & - & - \\
Control & + & $+/+$ & $+/-$ & $+/+$ & + & - \\
\hline
\end{tabular}

\section{Cross-protective effect of immunization with FP on lethal influenza infection of mice}

The course of infection in mice immunized with FP and challenged with homologous influenza virus

Our previous data showed that immunization of mice with three doses of FP conjugated to KLH significantly protected them against a lethal infection with $1 \mathrm{LD}_{50}$ of homologous virus A/Miss (Staneková et al., 2011). Here, even though the infective dose was increased to $2 \mathrm{LD}_{50}$, the protection induced by immunization was still observable. The immunization of mice $(n=15)$ with the FP conjugate significantly increased their survival from $7 \%$ in non-immunized control $(n=15)$ to $47 \%(\mathrm{p}=0.0352)$ (Fig. 5). Infectious virus titer in lungs reached a maximum on day 2 and decreased to undetectable levels on day 8 p.i. in both immunized and control mice (Fig. 6). However, a significantly lower titer (800) was observed on day 6 


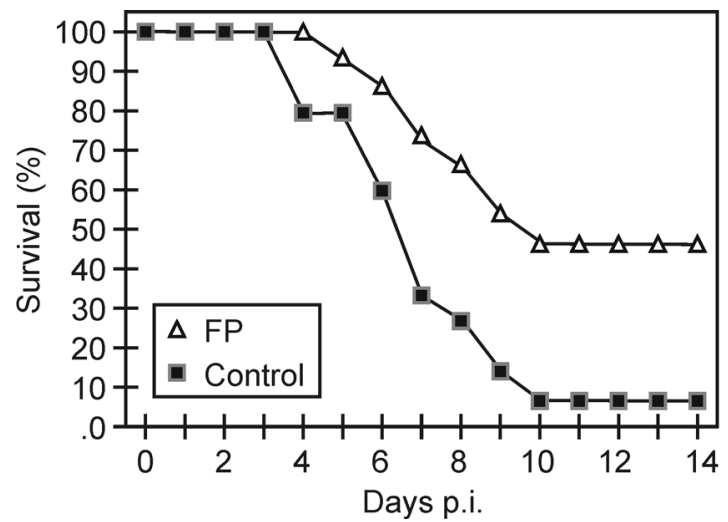

Fig. 5

Survival of mice immunized with FP and challenged with homologous influenza virus

p.i. in immunized mice compared to that in non-immunized control $(3,200)$. A clear elimination of infectious virus from lungs was observed by 2 days earlier in immunized mice compared to control mice (days 6 vs. 8) (Table 3).

Table 3. Detection of vRNA in lungs of mice immunized with FP and challenged with homologous virus

\begin{tabular}{lcccccc}
\hline \multirow{2}{*}{ Immunogen } & \multicolumn{7}{c}{ Days p.i. } \\
\cline { 2 - 7 } & 2 & 4 & 6 & 8 & 10 & 14 \\
\hline FP & + & $+/-$ & $+/-$ & - & - & - \\
Control & + & + & + & + & - & - \\
\hline
\end{tabular}

The course of infection in mice immunized with FP and challenged with heterologous influenza virus

The cross-protective potential of immunization with FP was examined similarly as described above except A/Rostock, a heterologous virus was used for challenge.

First clinical symptoms appeared on day 6 and mice died until day 12 p.i. in both immunized and control groups. However, a higher survival was observed in immunized mice compared to non-immunized control (71\% vs. 30\%, p = 0.1534) (Fig. 7).

From these results we can conclude that although FP is a weaker immunogen than EHA2, following potentiation of its immunogenicity by conjugation with KLH and adjuvanting with inulin and FA, it confers at least a partial protection against influenza infection.

\section{Discussion}

HA2 gp plays an important role in the virus entry into the cell. In our previous studies we have shown that MAbs

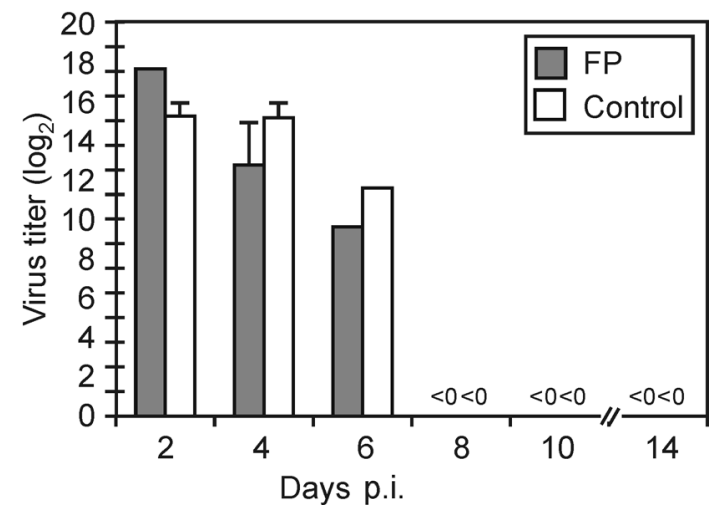

Fig. 6

Infectious virus in lungs of mice immunized with FP and challenged with homologous influenza virus

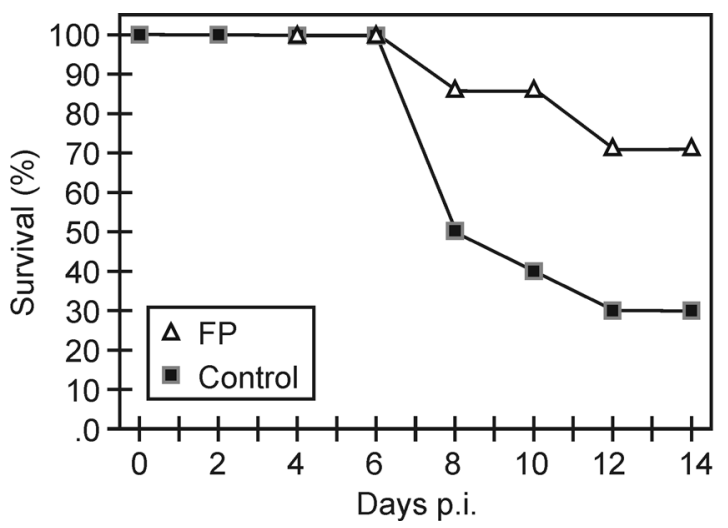

Fig. 7

Survival of mice immunized with FP and challenged with heterologous influenza virus

specific to HA2 gp, which are cross-reactive with different virus subtypes, inhibit the fusion activity of HA and reduce virus replication in vitro (Varečková et al., 2002, 2003a,b; Stropkovská et al., 2009). These MAbs, when passively applied, protected mice against lethal infection with IAVs of homologous or heterologous HA subtype (Gocník et al., 2007; Janulíková, unpublished data).

In this study, we used two fragments of HA2 gp as immunogens, namely EHA2 and FP, the most conserved part of HA. Analysis of the specific antibody response induced by three immunization doses showed that EHA2 is a stronger immunogen than FP. The efficacy of in vivo protection against the lethal infection with $2 \mathrm{LD}_{50}$ of homologous virus of $\mathrm{H} 3$ subtype was higher for EHA2 compared to FP (100\% vs $45 \%)$. However, in cotrast to the EHA2 immunization, the FP immunization increased survival of mice challenged with homologous or heterologous virus to a similar extent. 
These results are in accordance with previous data on protective immunity induced by immunization with HA2, which was expressed by recombinant vaccinia viruses (Gocník et al., 2008) or E. coli (Bommakanti et al., 2010). In this work, we purified EHA2 according to Chen et al. (1995). It was shown by crystalographic analysis that EHA2 purified in this way exhibits a low $\mathrm{pH}$ conformation (Chen et al., 1999). The antibodies induced by such an immunogen were cross-reactive with different virus subtypes (Janulíková, unpublished data) and were cross-protective, as demonstrated by the above results.

We can conclude that both peptides, EHA2 and FP can be used as inducers of heterosubtypic immunity. After their insertion into a suitable vector their antigenicity and crossprotectivity could be significantly enhanced (Staneková et al., in press) and widened. Based on our previous results, particular HA2 epitopes express different immunogenicity. In further protective studies, those of them which are more immunogenic and protective can be preferred (Staneková et al., 2012).

Acknowledgement. The authors thank Ms M. Mišovičová and M. Némethová for excellent technical assistance. This work was supported by the grants Nos. 2/0176/12 and 2/0101/10 from the Scientific Grant Agency of Ministry of Education of Slovak Republic and Slovak Academy of Sciences, and by grants Nos. 0250-10 and DO7RP-0025-2010 from Slovak Research and Development Agency.

\section{References}

Bommakanti G, Citron MP, Hepler RW, Callahan C, Heidecker GJ, Najar TA, Lu X, Joyce JG, Shiver JW, Casimiro DR, ter Meulen J, Liang X, Varadarajan R (2010): Design of an HA2-based Escherichia coli expressed influenza immunogen that protects mice from pathogenic challenge. Proc. Natl. Acad. Sci. USA 107, 13701-13706. http:// dx.doi.org/10.1073/pnas.1007465107

Cooper PD, Steele EJ (1988): The adjuvanticity of gamma inulin. Immunol. Cell Biol. 66, 345-352. http://dx.doi. org/10.1038/icb.1988.45

Corti D, Voss J, Gamblin SJ, Codoni G, Macagno A, Jarrossay D, Vachieri SG, Pinna D, Minola A, Vanzetta F, Silacci C, Fernandez-Rodriguez BM, Agatic G, Bianchi S, Giacchetto-Sasselli I, Calder L, Sallusto F, Collins P, Haire LF, Temperton N, Langedijk JP, Skehel JJ, Lanzavecchia A (2011): A neutralizing antibody selected from plasma cells that binds to group 1 and group 2 influenza A hemagglutinins. Science 333, 850-856. http://dx.doi. org/10.1126/science. 1205669

De Filette M, Ramne A, Birkett A, Lycke N, Löwenadler B, Min Jou W, Saelens X, Fiers W (2006): The universal influenza vaccine $\mathrm{M} 2 \mathrm{e}-\mathrm{HBc}$ administered intranasally in combination with the adjuvant CTA1-DD provides complete protection. Vaccine 24, 544-551.
De Filette M, Martens W, Roose K, Deroo T, Vervalle F, Bentahir M, Vandekerckhove J, Fiers W, Saelens X (2008a) An influenza $\mathrm{A}$ vaccine based on tetrameric ectodomain of matrix protein 2. J. Biol. Chem. 283, 11382-11387. http:// dx.doi.org/10.1074/jbc.M800650200

De Filette M, Martens W, Smet A, Schotsaert M, Birkett A, Londoño-Arcila P, Fiers W, Saelens X (2008b): Universal influenza A M2e-HBc vaccine protects against disease even in the presence of pre-existing anti-HBc antibodies. Vaccine 26, 6503-6507. http://dx.doi.org/10.1016/j. vaccine.2008.09.038

Fan J, Liang X, Horton MS, Perry HC, Citron MP, Heidecker GJ, Fu TM, Joyce J, Przysiecki CT, Keller PM, Garsky VM, Ionescu R, Rippeon Y, Shi L, Chastain MA, Condra JH, Davies ME, Liao J, Emini EA, Shiver JW (2004): Preclinical study of influenza virus A M2 peptide conjugate vaccines in mice, ferrets, and rhesus monkeys. Vaccine 22, 2993-3003. http://dx.doi.org/10.1016/j.vaccine.2004.02.021

Gerhard W, Mozdzanowska K, Zharikova D (2006): Prospects for universal influenza virus vaccine. Emerg. Infect. Dis. 12, 569-574. http://dx.doi.org/10.3201/eid1204.051020

Gocník M, Fislová T, Sládková T, Mucha V, Kostolanský F, Varečková E (2007): Antibodies specific to the HA2 glycopolypeptide of influenza A virus haemagglutinin with fusion-inhibition activity contribute to the protection of mice against lethal infection. J. Gen. Virol. 88, 951-955. http://dx.doi.org/10.1099/vir.0.82563-0

Gocník M, Fislová T, Mucha V, Sládková T, Russ G, Kostolanský F, Varečková E (2008): Antibodies induced by the HA2 glycopolypeptide of influenza virus haemagglutinin improve recovery from influenza A virus infection. J. Gen. Virol. 89, 958-967. http://dx.doi.org/10.1099/vir.0.83524-0

Horváth A, Tóth GK, Gogolák P, Nagy Z, Kurucz I, Pecht I, Rajnavölgyi E (1998): A hemagglutinin-based multipeptide construct elicits enhanced protective immune response in mice against influenza A virus infection. Immunol. Lett. 60, 127-136. http://dx.doi.org/10.1016/S01652478(97)00137-5

Hoelscher MA, Garg S, Bangari DS, Belser JA, Lu X, Stephenson I, Bright RA, Katz JM, Mittal SK, Sambhara S (2006): Development of adenoviral-vector-based pandemic influenza vaccine against antigenically distinct human $\mathrm{H} 5 \mathrm{~N} 1$ strains in mice. Lancet 367, 475-481. http://dx.doi.org/10.1016/ S0140-6736(06)68076-8

Huleatt JW, Nakaar V, Desai P, Huang Y, Hewitt D, Jacobs A, Tang J, McDonald W, Song L, Evans RK, Umlauf S, Tussey L, Powell TJ (2007): Potent immunogenicity and efficacy of a universal influenza vaccine candidate comprising a recombinant fusion protein linking influenza M2e to the TLR5 ligand flagellin. Vaccine 26, 201-208. http:// dx.doi.org/10.1016/j.vaccine.2007.10.062

Chen J, Skehel JJ, Wiley DC (1999): N- and C-terminal residues combine in the fusion-pH influenza hemagglutinin $\mathrm{HA}(2)$ subunit to form an $\mathrm{N}$ cap that terminates the triple-stranded coiled coil. Proc. Natl. Acad. Sci. USA 96, 8967-8972. http://dx.doi.org/10.1073/pnas.96.16.8967 
Chen J, Wharton SA, Weissenhorn W, Calder LJ, Hughson FM, Skehel JJ, Wiley DC (1995): A soluble domain of the membrane-anchoring chain of influenza virus hemagglutinin (HA2) folds in Escherichia coli into the low-pH-induced conformation. Proc. Natl. Acad. Sci. USA 92, 1220512209. http://dx.doi.org/10.1073/pnas.92.26.12205

Király J, Varečková E, Mucha V, Kostolanský F (2011): Evaluation of anti-influenza efficiency of polyclonal IgG antibodies specific to the ectodomain of M2 protein of influenza A virus by passive immunization of mice. Acta Virol. 55, 261-265. http://dx.doi.org/10.4149/av 2011 $03 \quad 261$

Li R, Lim A, Ow ST, Phoon MC, Locht C, Chow VT, Alonso S (2011): Development of live attenuated Bordetella pertussis strains expressing the universal influenza vaccine candidate M2e. Vaccine 29, 5502-5511. http://dx.doi. org/10.1016/j.vaccine.2011.05.052

Liu W, Peng Z, Liu Z, Lu Y, Ding J, Chen YH (2004): High epitope density in a single recombinant protein molecule of the extracellular domain of influenza A virus M2 protein significantly enhances protective immunity. Vaccine 23, 366371. http://dx.doi.org/10.1016/j.vaccine.2004.05.028

Nobusawa E, Aoyama T, Kato H, Suzuki Y, Tateno Y, Nakajima K (1991): Comparison of complete amino acid sequences and receptor-binding properties among 13 serotypes of hemagglutinins of influenza A viruses. Virology 182, 475485. http://dx.doi.org/10.1016/0042-6822(91)90588-3

Okuda K, Ihata A, Watabe S, Okada E, Yamakawa T, Hamajima K, Yang J, Ishii N, Nakazawa M, Okuda K, Ohnari K, Nakajima K, Xin KQ(2001): Protective immunity against influenza A virus induced by immunization with DNA plasmid containing influenza M gene. Vaccine 19, 3681-3691. http://dx.doi.org/10.1016/S0264-410X(01)00078-0

Okuno Y, Isegawa Y, Sasao F, Ueda S (1993): A common neutralizing epitope conserved between the hemagglutinins of influenza A virus $\mathrm{H} 1$ and $\mathrm{H} 2$ strains. J. Virol. 67, 2552-2558.

Park KS, Seo YB, Lee JY, Im SJ, Seo SH, Song MS, Choi YK, Sung YC (2011): Complete protection against a H5N2 avian influenza virus by a DNA vaccine expressing a fusion protein of H1N1 HA and M2e. Vaccine 29, 5481-5487. http://dx.doi.org/10.1016/j.vaccine.2011.05.062

Petrovsky N (2006): Novel human polysaccharide adjuvants with dual Th1 and Th2 potentiating activity. Vaccine 24 (Suppl.), S2-26-29.

Prabhu N, Prabakaran M, Ho HT, Velumani S, Qiang J, Goutama M, Kwang J (2009): Monoclonal antibodies against the fusion peptide of hemagglutinin protect mice from lethal influenza A virus H5N1 infection. J. Virol. 83, 2553-2562. http://dx.doi.org/10.1128/JVI.02165-08

Russ G, Varečková E, Styk B (1974): Steric effects in the reaction of influenza virus neuraminidase with antibodies. Acta Virol 18, 299-306.

Staneková Z, Király J, Stropkovská A, Mikušková T, Mucha V, Kostolanský F, Varečková E (2011): Heterosubtypic protective immunity against influenza $A$ virus induced by fusion peptide of the hemagglutinin in comparison to ectodomain of M2 protein. Acta Virol. 55, 61-67. http:// dx.doi.org/10.4149/av $201101 \quad 61$
Staneková Z, Mucha V, Sládková T, Blaškovičová $H$, Kostolanský F, Varečková E (2012): Epitope specificity of anti-HA2 antibodies induced in humans during influenza infection. Influenza Other Respi Viruses. 2012 Jan 12. doi: 10.1111/j.1750-2659.2011.00328.x. [Epub ahead of print] http://dx.doi.org/10.1111/j.1750-2659.2011.00328.x

Staneková Z, Adkins I, Kosová M, Janulíková J, Šebo P, Varečková E.: Heterosubtypic protection against influenza induced by adenylate cyclase toxoids delivering conserved HA2 subunit of hemagglutinin. Antiviral Res. (in press).

Steel J, Lowen AC, Wang T, Yondola M, Gao Q, Haye K, Garcia-Sastre A, Palese P (2010): An Influenza virus vaccine based on the conserved hemagglutinin stalk domain. MBio 1:e00018-10. http://dx.doi.org/10.1128/mBio.00018-10

Stropkovská A, Mucha V, Fislová T, Gocník M, Kostolanský F, Varečková E (2009): Broadly cross-reactive monoclonal antibodies against HA2 glycopeptide of Influenza A virus hemagglutinin of $\mathrm{H} 3$ subtype reduce replication of influenza A viruses of human and avian origin. Acta Virol. 53, 15-20.

Styk B, Russ G, Poláková K (1979): Antigenic glycopolypeptides HA1 and HA2 of influenza virus haemagglutinin. III. Reactivity with human convalescent sera. Acta Virol. 23, 1-8.

Sui J, Hwang WC, Perez S, Wei G, Aird D, Chen LM, Santelli E, Stec B, Cadwell G, Ali M, Wan H, Murakami A, Yammanuru A, Han T, Cox NJ, Bankston LA, Donis RO, Liddington RC, Marasco WA (2009): Structural and functional bases for broad-spectrum neutralization of avian and human influenza A viruses. Nat. Struct. Mol. Biol. 16, 265-273. http://dx.doi.org/10.1038/nsmb.1566

Throsby M, van den Brink E, Jongeneelen M, Poon LL, Alard P, Cornelissen L, Bakker A, Cox F, van Deventer E, Guan Y, Cinatl J, ter Meulen J, Lasters I, Carsetti R, Peiris M, de Kruif J, Goudsmit J (2008): Heterosubtypic neutralizing monoclonal antibodies cross-protective against H5N1 and $\mathrm{H} 1 \mathrm{~N} 1$ recovered from human IgM+ memory B cells. PLoS One 3(12):e3942. http://dx.doi.org/10.1371/journal. pone. 0003942

Tkáčová M, Varečková E, Baker IC, Love JM, Ziegler T (1997): Evaluation of monoclonal antibodies for subtyping of currently circulationg human type A influenza viruses. J. Clin. Microbiol. 35, 1196-1198.

Varečková E, Mucha V, Čiampor F, Betáková T, Russ G (1993): Monoclonal antibodies demonstrate accessible HA2 epitopes in minor subpopulation of native influenza haemagglutinin molecules. Arch. Virol. 130, 45-56. http:// dx.doi.org/10.1007/BF01318995

Varečková E, Betáková T, Mucha V, Soláriková L, Kostolanský F, Waris M, Russ G (1995): Preparation of monoclonal antibodies for the diagnosis of influenza A infection using different immunization protocols. J. Immunol. Methods 180, 107116. http://dx.doi.org/10.1016/0022-1759(94)00307-I

Varečková E, Blaškovičová H, Gocník M, Mikas J, Adamčáková J, Fislová T, Kostolanský F, Mucha V (2006): Evaluation of clinical specimens for influenza A positivity using various diagnostic methods. Acta Virol. 50, 181-186. 
Varečková E, Cox N, Klimov A (2002): Evaluation of subtype specifity of monoclonal antibodies raised against $\mathrm{H} 1$ and $\mathrm{H} 3$ subtypes of human influenza A virus hemagglutinins. J. Clin. Microbiol. 40, 2220-2223. http://dx.doi. org/10.1128/JCM.40.6.2220-2223.2002

Varečková E, Mucha V, Wharton SA, Kostolanský F (2003a): Inhibition of fusion activity of influenza A haemagglutinin mediated by HA2-specific monoclonal antibodies. Arch. Virol. 148, 469-486. http://dx.doi.org/10.1007/s00705-002-0932-1

Varečková E, Wharton SA, Mucha V, Gocník M, Kostolanský F (2003b): A monoclonal antibody specific to the HA2 glycoprotein of influenza A virus hemagglutinin that inhibits its fusion activity reduces replication of the virus. Acta Virol. 47, 229-236.

Varečková E, Mucha V, Kostolanský F, Gubareva L, Klimov A (2008): HA2-specific monoclonal antibodies as tools for differential recognition of influenza A virus antigenic subtypes. Virus Res. 132, 181-186. http://dx.doi. org/10.1016/j.virusres.2007.10.004
Wang TT, Tan GS, Hai R, Pica N, Ngai L, Ekiert DC, Wilson IA, García-Sastre A, Moran TM, Palese P (2010): Vaccination with a synthetic peptide from the influenza virus hemagglutinin provides protection against distinct viral subtypes. Proc. Natl. Acad. Sci. USA 107, 18979-18984. http://dx.doi.org/10.1073/pnas.1013387107

Yoshida R, Igarashi M, Ozaki H, Kishida N, Tomabechi D, Kida H, Ito K, Takada A (2009): Cross-protective potential of a novel monoclonal antibody directed against antigenic site B of the hemagglutinin of influenza A viruses. PLoS Pathog. 5:e1000350. http://dx.doi.org/10.1371/journal. ppat. 1000350

Zhang GG, Li DX, Zhang HH, Zeng YM, Chen L (2009): Enhancement of mucosal immune response against the $\mathrm{M} 2 \mathrm{eHBc}+$ antigen in mice with the fusion expression products of $\mathrm{LTB}$ and $\mathrm{M} 2 \mathrm{eHBc}+$ through mucosal immunization route. Vet. Res. Commun. 33, 735-747. http://dx.doi. org/10.1007/s11259-009-9222-7 